\title{
PENGATURAN KEWENANGAN PEMBUATAN AKTA PERTANAHAN ANTARA NOTARIS DAN PEJABAT PEMBUAT AKTA TANAH ${ }^{1}$
}

\author{
Adi Rahayu \\ Program Magister Kenotariatan Fakultas Hukum Universitas Jambi
}

\begin{abstract}
Abstrak
Artikel ini membahas pengaturan kewenangan pembuatan akta pertanahan antara notaris dan Pejabat Pembuat Akta Tanah. Dalam pembuatan akta pertanahan, kewenangan notaris bersumber dari atribusi yang melekat pada profesi notaris, sedangkan kewenangan PPAT bersumber dari delegasi atau pelimpahan wewenang dari pejabat yang berwenang, dalam hal ini Badan Pertanahan Nasional. Akta pertanahan yang dibuat oleh atau di hadapan notaris merupakan akta autentik dan memiliki kekuatan pembuktian sempurna, sedangkan yang dikeluarkan PPAT tidak memenuhi syarat akta autentik dan hanya memiliki kekuatan pembuktian akta di bawah tangan.
\end{abstract}

Kata kunci: akta pertanahan, notaris, PPAT

\begin{abstract}
This article discusses the regulation-making authority between the notary and Pejabat Pembuat Akta Tanah (PPAT). In making the land deed, notary authority derived from attribution attached to the profession of notary, whereas PPAT authority derived from a delegate or delegation of authority from the competent authority, in this case Badan Pertanahan Nasional. Deed of land made by or in the presence of a notary deed is authentic and has the strength of evidence is perfect, while issued PPAT ineligible authentic deed and only has the strength of evidence deed under hand.
\end{abstract}

Keyword: the land act, notary, PPAT

\section{Pendahuluan}

Pendaftaran tanah sebagai "perintah Pasal 19 Undang-Undang Nomor 5 Tahun 1960 Tentang Peraturan Dasar Pokok-Pokok Agraria "inilah sebagai cikal dasar pendaftaran tanah di Indonesia" ${ }^{2}$ yang kemudian ditindak lanjuti dengan diterbitkannya Peraturan Pemerintah Nomor 10 Tahun 1961 Tentang Pendaftaran Tanah yang telah dirubah

\footnotetext{
${ }^{1}$ Artikel ini adalah ringkasan tesis yang berjudul "Pengaturan Kewenangan Pembuatan Akta Pertanahan Antara Notaris Dan Pejabat Pembuat Akta Tanah (PPAT)" yang ditulis oleh Adi Rahayu di bawah bimbingan Prof. Sukamto Satoto pada Program Studi Magister Kenotariatan Fakultas Hukum Universitas Jambi, Jambi 2015.

2 Elita Rahmi, Hukum Pertanahan Dalam Sistem Hukum Indonesia, Unpad Press, Bandung, 2011, hal.129.
} 
dengan Peraturan Pemerintah Nomor 24 Tahun 1997 Tentang Pendaftaran Tanah atas dasar inilah kemudian dikenal adanya Pejabat Pembuat Akta Tanah (PPAT).

Pasal 37 Peraturan Pemerintah Nomor 24 Tahun 1997 Tentang Pendaftaran Tanah menyatakan bahwa sebagai berikut:

1) Peralihan hak atas tanah dan hak milik atas satuan rumah susun melalui jual beli, tukar menukar, hibah, pemasukan dalam perusahaan dan perbuatan hukum pemindahan hak lainnya, kecuali pemindahan hak melalui lelang hanya dapat didaftarkan jika dibuktikan dengan akta yang dibuat oleh PPAT yang berwenang menurut ketentuan peraturan perundang-undangan yang berlaku.

2) Dalam keadaan tertentu sebagaimana yang ditentukan oleh Menteri Kepala Kantor Pertanahan dapat mendaftar pemindahan hak atas bidang tanah hak milik, yang dilakukan di antara perorangan warga negara Indonesia yang dibuktikan dengan akta yang tidak dibuat oleh PPAT, tetapi yang menurut Kepala Kantor Pertanahan tersebut kadar kebenarannya dianggap cukup untuk mendaftar pemindahan hak yang bersangkutan.

Berdasarkan ketentuan Pasal 1 angka (1) Peraturan Pemerintah Nomor 38 Tahun 1998 Tentang Peraturan Jabatan Pembuat Akta Tanah yang disebut Pejabat Pembuat Akta Tanah, selanjutnya disebut PPAT, adalah Pejabat umum yang diberi kewenangan untuk membuat akta-akta autentik mengenai perbuatan hukum tertentu mengenai hak atas tanah atau Hak Milik Atas Satuan Rumah Susun. Selain Istilah PPAT dikenal juga istilah PPAT Sementara dan PPAT Khusus yaitu:

1) PPAT Sementara merupakan Pejabat Pemerintah yang ditunjuk karena jabatannya untuk melaksanakan tugas PPAT dengan membuat akta PPAT di daerah yang belum cukup terdapat PPAT sedangkan

2) PPAT Khusus ialah adalah Pejabat Badan Pertanahan Nasional yang ditunjuk karena jabatannya untuk melaksanakan tugas PPAT dengan membuat akta PPAT tertentu khusus dalam rangka pelaksanaan program atau tugas Pemerintah tertentu.

"Pejabat Pembuat Akta Tanah (PPAT) dikualifikasikan sebagai Pejabat umum dan diberi kewenangan untuk membuat akta-akta tertentu di bidang peralihan dan pembebanan hak atas tanah"3 adapun tugas pokok dan kewenangan PPAT berdasarkan Pasal 2 ayat (1) dan (2) Peraturan Pemerintah Nomor 37 Tahun 1998 Tentang Pejabat Pembuat Akta Tanah sebagai berikut:

1) PPAT bertugas pokok melaksanakan sebagian kegiatan pendaftaran tanah dengan membuat akta sebagai bukti telah dilakukannya perbuatan hukum tertentu mengenai hak atas tanah atau Hak Milik Atas Satuan Rumah Susun,

\footnotetext{
${ }^{3}$ Habib Adjie, Merajut Pemikiran dalam Dunia Notaris dan PPAT, PT. Citra Aditya Bakti, Bandung, 2014, hal.91.
} 
yang akan dijadikan dasar bagi pendaftaran perubahan data pendaftaran tanah yang diakibatkan oleh perbuatan hukum itu.

2) Perbuatan hukum sebagaimana dimaksud pada ayat (1) adalah sebagai berikut:
a. jual beli
b. tukar menukar
c. hibah
d. pemasukan ke dalam perusahaan (inbreng)
e. pembagian hak bersama
f. pemberian Hak Guna Bangunan/ Hak Pakai atas Tanah Hak Milik
g. pemberian Hak Tanggungan
h. pemberian Kuasa membebankan Hak Tanggungan

Pendaftaran tanah dan peralihan hak atas tanah tidak terlepas dengan apa yang disebut akta autentik dan sudah barang tentu Pejabat umum yang berwenang membuat akta autentik adalah PPAT tidak terkecuali juga Notaris, kewenangan Notaris berdasarkan sejarah panjang Notaris di Indonesia antara lain diatur dalam Pasal 1 Peraturan Jabatan Notaris (Staatsblad 1860 Nomor 3) bahwa yang dimaksud dengan Notaris adalah Pejabat umum yang satu-satunya berwenang untuk membuat akta autentik mengenai semua perbuatan, perjanjian, dan penetapan yang diharuskan oleh suatu peraturan umum atau oleh yang berkepentingan dikehendaki untuk dinyatakan dalam suatu akta autentik, menjamin kepastian tanggalnya, menyimpan aktanya dan memberikan grosse, salinan dan kutipannya, semuanya sepanjang pembuatan akta itu oleh suatu peraturan umum tidak juga ditugaskan atau dikecualikan kepada Pejabat atau orang lain.

Lahirnya Undang-Undang Nomor 2 Tahun 2014 Tentang Perubahan Atas Undang-Undang Nomor 30 Tahun 2004 Tentang Jabatan Notaris, memberikan akibat yang dulunya Notaris dalam menjalankan tugasnya berdasarkan pada peraturan peninggalan Belanda yakni Reglement Op Het Notaris Ambt In Indonesie (Stb. 1860:3). Sekarang Notaris merasa mendapatkan angin segar dengan disahkannya undang-undang ini yang mana sebelumnya "Notaris hanya memiliki tugas pokok yaitu untuk membuat akta autentik mengenai semua perbuatan, perjanjian dan penetapan" ${ }^{4}$ sekarang Notaris mendapatkan perluasan kewenangan yaitu membuat akta yang berkaitan dengan pertanahan (Pasal 15 ayat (2) huruf f Undang-Undang Nomor 2 Tahun 2014 Tentang Perubahan Atas Undang-Undang Nomor 30 Tahun 2004 Tentang Jabatan Notaris,

${ }^{4}$ Ibid., hal. 31. 
sebagaimana diketahui sebelumnya bahwa kewenangan ini adalah kewenangan Pejabat Pembuat Akta Tanah (PPAT). Menurut Farida Patittingi dalam kondisi demikian, jika terjadi konflik hukum yang mengatur hal yang sama, dapat diselesaikan dengan menggunakan asas hukum, yaitu:

1) Lex porteriori derogate legi priori, artinya peraturan atau undang-undang yang terbaru mengesampingkan peraturan atau undang-undang yang lama yang mengatur hal yang sama.

2) Lex superior derogate legi inferiori, artinya jika terjadi pertentangan antara peraturan perundang-undangan yang tinggi dengan yang rendah, maka yang tinggilah yang harus didahulukan. ${ }^{5}$

Kedua asas hukum tersebut, secara otomatis mengesampingkan peraturan Jabatan PPAT yang diatur dalam peraturan sebelumnya, apalagi Peraturan Pemerintah Nomor 37 Tahun 1998 Tentang Jabatan Pejabat Pembuat Akta Tanah kedudukannya lebih rendah dari Undang-Undang Jabatan Notaris karena bentuknya hanya Peraturan Pemerintah.",6

"Tetapi pada sisi lain, dapat juga menggunakan asas hukum "lex specialis derogate legi generale", sehingga peraturan khusus akan mengesampingkan peraturan umum yang mengatur hal yang sama."7 "Artinya Peraturan Pemerintah Nomor 37 Tahun 1998 Tentang Jabatan Pejabat Pembuat Akta Tanah yang secara khusus mengatur Jabatan PPAT yang berlaku saat ini dapat dikategorikan sebagai lex specialis." "dalam kondisi demikian, mana yang harus diikuti, tidak memberikan penyelesaian dan kepastian hukum. Untuk itu memang dibutuhkan adanya harmonisasi hukum dalam pembuatan suatu peraturan perundang-undangan." 9

Perebutan kewenangan ini dinilai wajar, pada kenyataan bahwa jika Notaris tidak merangkap jabatan sebagai Pejabat Pembuat Akta Tanah (PPAT) dalam menjalankan tugasnya dirasa tidak lengkap, sehingga klien Notaris baik perorangan, korporasi maupun perbankan merasa tidak puas atas pelayanan Notaris yang belum PPAT, dengan kewenangan Notaris untuk membuat akta pertanahan telah melekat pada diri Notaris diharapkan Notaris tidak lagi harus merangkap jabatan untuk satu wilayah kerja dalam menjalankan tugasnya.

\footnotetext{
${ }^{5}$ Farida Patittingi, "Keberadaan Profesi Pejabat pembuat Akta Tanah (PPAT) di Tengah Kontroversi Payung Hukum”, http://ippatonline.com. hal.6.

${ }^{6}$ Ibid.

${ }^{7}$ Ibid.

${ }^{8}$ Ibid.hal 7.

${ }^{9}$ Ibid.
} 
"Namun dengan bertambahnya kewenangan Notaris ini pada perkembangannya masih belum bisa dilaksanakan," ${ }^{10}$ jika melihat sejarah panjang dan jalan berliku peraturan jabatan Notaris menurut Badar Baraba:

Dalam pansus revisi Undang-Undang Nomor 30 Tahun 2004 Tentang Jabatan Notaris Pasal 15 ayat (2) huruf (f) tentang kewenangan Notaris membuat akta pertanahan dalam pansus sudah muncul tetapi belum begitu jelas kemudian baru di panja dipertahankan dan ketika rapat paripurna DPR RI yang berlangsung 17 Desember 2013 rancangan UUJN disahkan. Seharusnya jika berbicara kewenangan Notaris membuat akta autentik tentu tidak ada pengecualian termasuk juga dalam membuat akta di bidang pertanahan. Namun pendaftaran tetap ada atau menjadi kewenangan BPN RI dan aktanya juga dapat dibuat secara Notariil. ${ }^{11}$

Hal ini senada dengan yang dikemukakan oleh Arry Suprapto yang mengemukakan antara lain:

bahwa sebetulnya filosofi Pasal 15 ayat (2) huruf f Undang-Undang Nomor 2 Tahun 2014 Tentang Perubahan Atas Undang-Undang Nomor 30 Tahun 2004 Tentang Jabatan Notaris kalau kita kembali kebelakang pada waktu pembahasan RUUJN menjadi Undang-Undang pola pikirnya adalah kita sebagai organisasi dan kita adalah satu-satunya profesi yang dipercaya pemerintah ingin berbuat semaksimal mungkin mengurangi beban pemerintah. ${ }^{12}$ Hal ini dalam kaitannya membuat bukti-bukti autentik secara tertulis. Disitulah pola pikirnya karena kita melihat betapa kasihannya intitusi pemerintah yang bernama BPN yang terganggu kerjanya dan tidak bisa memaksimalkan kerjanya hanya karena persoalan mengurusi blangko. ${ }^{13}$

Kemudian lebih lanjut Nonny W Warmana Notaris dan PPAT Kota Bandung yang sekaligus Ketua PPAT Kota Bandung sebagaimana dikutip oleh Badar Baraba menyatakan:

Kewenangan Notaris membuat akta pertanahan karena telah ditetapkan dalam UUJN setuju atau tidak setuju semua lembaga negara termasuk BPN harus melaksanakan dan patuh terhadap Undang-undang ini karena sebelumnya tidak ada singkronisasi dari lembaga terkait maka disarankan Kementrian Hukum dan ham harus koordinasi dengan BPN RI bagaimana mekanisme pelasanaan Pasal ini termasuk tanggung jawab DPR RI karena selain pembuat Undang-Undang juga harus menjadi pengawas dalam pelaksaan Undangundang ini. $^{14}$

\footnotetext{
${ }^{10}$ Habib Adjie, Menjalin Pemikiran-Pendapat Tentang Kenotariatan (Kumpulan Tulisan), PT. Citra Aditya Bakti, Bandung, 2013, hal. 19.

${ }_{11}^{11}$ Majalah Bulanan Notaris, PPAT, Pertanahan dan Hukum Renvoi, Nomor 9, 29 Februari 2014, hal. 14.

${ }^{12} \mathrm{Ibid}$

${ }^{13}$ Ibid.

${ }^{14}$ Ibid., hal. 23.
} 
Berdasarkan latar belakang di atas tentang ketentuan peraturan-peraturan yang mengatur tentang kewenangan baik PPAT maupun Notaris dalam membuat akta pertanahan terdapat kesamaan kewenangan bahkan dapat dikatakan terdapat tumpang tindih kewenangan dalam 2 (dua) profesi dan atau jabatan yang sama-sama bersumber dari peraturan perundang-undangan atas dasar inilah penulis merasa tertarik untuk meneliti dan menulis jurnal yang berjudul pengaturan kewenangan pembuatan akta pertanahan antara Notaris dan Pejabat pebuat akta tanah (PPAT). Berdasarkan uraian latar belakang di atas, rumusan masalah yang akan dibahas dalam penelitian dan penulisan tesis ini adalah: 1). Bagaimana pengaturan kewenangan pembuatan akta pertanahan antara Notaris dan Pejabat Pebuat Akta Tanah (PPAT)? 2). Apa akibat hukum terhadap akta pertanahan yang dibuat oleh atau di hadapan Notaris dan yang dibuat oleh Pejabat Pebuat Akta Tanah (PPAT)?

Untuk menjawab dan membahas permasalahan tersebut, artikel yang berasald ari penelitian ini menggunakan metode tertentu. Menurut Peter R. Seen, metode merupakan "suatu prosedur atau cara mengetahui sesuatu menggunakan langkah-langkah yang sistematis." ${ }^{15}$ Definisi lain menurut Wolman metode sebagai teknik dan prosedur pengamatan dan percobaan yang menyelidiki alam yang digunakan oleh ilmuwan untuk mengolah fakta- fakta, data dan penafsirannya sesuai dengan asas-asas dan aturanaturan tertentu."16 Bertolak dari kedua pendapat di atas untuk menjawab suatu permasalahan dalam penelitian ini peneliti memutuskan untuk melakukan penelitian dengan metode penelitian yang ajek dan sistematis agar memperoleh suatu jawaban yang benar dan akurat sesuai dengan disiplin ilmu hukum sebagai berikut.

Tipe penelitian yang dilakukan dalam penelitian dan penulisan ini merupakan penelitian hukum secara juridis normatif, berkenaan dengan hal ini yang menjadi objek penelitian merupakan isu hukum yang berkaitan dengan kewenangan pembuatan akta pertanahan antara Notaris dan Pejabat Pebuat Akta Tanah (PPAT).

Pendekatan yang digunakan adalah penelitian juridis normatif antara lain:

a. "Metode pendekatan Perundang-undang (Statute approach).

b. "Metode pendekatan konseptual (conceptual approach)

c. Metode pendekatan sejarah (historical approach)

\footnotetext{
${ }^{15}$ Bahder Johan Nasution, Metode Penelitian Ilmu Hukum, Mandar Maju, Bandung, 2008, hal. 3.

${ }^{16}$ Ibid.
} 


\section{Pembahasan}

Kewenangan Pembuatan Akta Pertanahan Antara Notaris Dan Pejabat Pembuat Akta Tanah (PPAT)

Pada tahun 2014 Muhammad Thoha mengajukan permohonan pengujian terhadap Undang-Undang Nomor 30 Tahun 2004 Tentang Jabatan Notaris Sebagamana telah dirubah dengan Undang-Undang Nomor 2 Tahun 2014 Tentang Perubahan Atas Undang-Undang Nomor 30 Tahun 2004 Tentang Jabatan Notaris terhadap UndangUndang Dasar Negara Republik Indonesia Tahun 1945 yaitu pada tanggal 30 Desember 2014 yang diterima di Kepaniteraan Mahkamah Konstitusi (Kepaniteraan Mahkamah) berdasarkan akta penerimaan berkas permohonan nomor 21/PAN.MK/2014 dan telah dicacat dalam buku register perkara konstitusi dengan nomor 5/PUU-XII/2014 pada tanggal 15 Januari 2014, yang kemudian telah diperbaiki dengan perbaikan yang diterima di persidangan Mahkamah tanggal 4 Februari 2014 dan perbaikan yang diserahkan melalui Kepaniteraan tanggal 10 Februari 2014, dengan Putusan Nomor 5/PUU-XII/2014 dalam konklusi Mahkamah berkesimpulan:

1) Mahkamah berwenang untuk mengadili permohonan Pemohon

2) Pemohon memiliki kedudukan hukum (legal standing) untuk mengajukan permohonan Pemohon

3) Pokok permohonan Pemohon tidak beralasan menurut hukum

Kemudian dalam amar putusannya menyebutkan mengadili, menyatakan menolak permohonan Pemohon untuk seluruhnya.

Peneliti dengan ini menyatakan sependapat dengan pendapat Mahkamah Konstitusi dan hasil Putusannya atas permohonan pengujian Undang-Undang Nomor 30 Tahun 2004 Tentang Jabatan Notaris Sebagaimana telah dirubah dengan UndangUndang Nomor 2 Tahun 2014 Tentang Perubahan Atas Undang-Undang Nomor 30 Tahun 2004 Tentang Jabatan Notaris terhadap Undang-Undang Dasar Negara Republik Indonesia Tahun 1945 yang menyatakan mengadili, menolak permohonan Pemohon untuk seluruhnya, dan dengan demikian dapat diartikan bahwa ketentuan Pasal 15 Ayat (2) huruf f Undang-Undang Nomor 2 Tahun 2014 Tentang Perubahan Atas UndangUndang Nomor 30 Tahun 2004 Tentang Jabatan Notaris yang diuji tidak bertentangan dengan Undang-Undang Dasar Negara Republik Indonesia Tahun 1945.

Dengan demikian sebaiknya untuk dapat mengkaji lebih dalam apakah ketentuan Pasal 15 Ayat (2) huruf f Undang-Undang Nomor 2 Tahun 2014 Tentang Perubahan Atas Undang-Undang Nomor 30 Tahun 2004 Tentang Jabatan Notaris tidak multi tafsir 
atau bahkan tidak bertentangan dengan ketentuan Peraturan Pemerintah Nomor 37 Tahun 1998 Tentang Peraturan Jabatan Pejabat Pembuat Akta Tanah, para pihak yang berkepentingan mengajukan gugatan kepada Mahkamah Agung sesuai dengan kewenangannya yaitu menguji menguji peraturan perundang-undangan di bawah undang-undang terhadap undang-undang sesuai dengan ketentuan Pasal 24A Ayat (1) Undang-Undang Dasar Negara Republik Indonesia Tahun 1945.

\section{Mengklasifikasi, Mensistematisasi dan Menginterpretasi Peraturan Perundang- Undangan Terkait Kewenangan Pembuatan Akta Yang Berkaitan Dengan Pertanahan Antara Notaris Dan Pejabat Pembuat Akta Tanah}

Setelah peneliti mengklasifikasi, mensistematisasi, dan menginterpretasikan seluruh peraturan perundang-undangan yang berkaitan dengan kewenangan pembuatan akta pertanahan yang berkaitan dengan pertanahan antara Notaris dan Pejabat Pembuat Akta Tanah (PPAT), untuk dapat mengetahui maksud dan tujuan dari Pasal 15 ayat (2) huruf f Undang-Undang Nomor 2 Tahun 2014 Tentang Perubahan Atas Undang-Undang Nomor 30 Tahun 2004 Tentang Jabatan Notaris tidaklah hanya dengan membaca secara harfiah kata-kata dalam Pasal tersebut, tetapi haruslah dipahami sebagai suatu sistem yang tidak terpisahkan dengan Pasal-Pasal lainnya, penjelasan Pasal-Pasal dan penjelasan umum dari UUJN, maupun risalah rapat proses pembahasan rancangan undang-undang tentang jabatan Notaris serta dengan seluruh peraturan-peraturan yang berlaku dalam sistem hukum nasional secara keseluruhan. Untuk memahami Pasal 15 ayat (2) huruf f Undang-Undang Nomor 2 Tahun 2014 Tentang Perubahan Atas Undang-Undang Nomor 30 Tahun 2004 Tentang Jabatan Notaris setidaknya haruslah dihubungkan dengan Pasal 17 huruf g UUJN, dan menurut Mahkamah Konstitusi dihubungkan dengan Pasal 2 Peraturan Pemerintah Nomor 37 tahun 1998 Tentang Peraturan Jabatan Pejabat Pembuat Akta, Ketentuan yang demikian dalam ilmu hukum dikenal dengan kmetode penafsiran secara "interpretasi sistematis atau logis."

Jika mengulas kewenangan PPAT dalam Pasal 2 Peraturan Pemerintah Nomor 37 tahun 1998 Tentang Peraturan Jabatan Pejabat Pembuat Akta Tanah dikaitkan dengan ketentuan Pasal 15 ayat (2) huruf f Undang-Undang Nomor 2 Tahun 2014

\footnotetext{
${ }^{17}$ Sudikno Mertokusumo, Penemuan Hukum Sebuah Pengantar, Liberty, Yogyakarta, 2009.
} 
Tentang Perubahan Atas Undang-Undang Nomor 30 Tahun 2004 Tentang Jabatan Notaris dengan metode "interpretasi gramatikal"18 dapat ditafsirkan PPAT hanya memiliki tugas pokok mendaftarkan sebagian kegiatan pendaftaran tanah saja dengan demikian terdapat ruang bagi notaris untuk melaksanakan tugas sebagaimana maksud dan tujuan dari kewenangan Notaris dalam Pasal 15 ayat (2) huruf f Undang-Undang Nomor 2 Tahun 2014 Tentang Perubahan Atas Undang-Undang Nomor 30 Tahun 2004 Tentang Jabatan Notaris.

Dengan demikian peneliti sependapat dengan pendapat yang dikemukakan oleh Habib Adjie tentang arti ketentuan Pasal 15 ayat (2) huruf f Undang-Undang Nomor 2 Tahun 2014 Tentang Perubahan Atas Undang-Undang Nomor 30 Tahun 2004 Tentang Jabatan Notaris yaitu:

1. Kewenangan Notaris membuat akta yang berkaitan dengan pertanahan sepanjang bukan tindakan hukum dalam bentuk:
a. jual beli
b. tukar menukar
c. hibah
d. pemasukan ke dalam perusahaan (inbreng)
e. pembagian hak bersama
f. pemberian Hak Guna Bangunan/Hak Pakai atas Tanah Hak Milik
g. pemberian Hak Tanggungan
h. pemberian Kuasa membebankan Hak Tanggungan

2. Karena tindakan hukum tersebut mutlak wewenang Pejabat Pembuat Akta Tanah (PPAT) Pasal 95 Peraturan Menteri Negara Agraria/ Kepala Badan Pertanahan Nasional Nomor 3 Tahun 1997 Tentang Ketentuan Pelaksana Peraturan Pemerintah Nomor 24 Tahun 1997 Tentang Pendaftaran Tanah juncto Pasal 2 ayat (2) Peraturan Pemerintah Nomor 37 Tahun 1998 Tentang Peraturan Jabatan Pejabat Pembuat Akta Tanah. ${ }^{19}$

Kemudian analisis menggunakan interpretasi sistematis atau logis terhadap dengan ketentuan Pasal 17 Huruf g UUJN dikaitkan dengan Pasal 15 Ayat 2 Huruf $\mathrm{f}$ UUNJ mempunyai arti:

1) bahwa Notaris boleh merangkap jabatan sebagai PPAT asal saja jabatan PPAT yang dirangkapnya masih masuk dalam wilayah jabatan Notaris

2) dengan adanya pengakuan jabatan rangkap ini maka Notaris dan PPAT mempunyai kewenangan yang berbeda atau kewenangan Notaris menurut UUJN tidak sama dengan kewenangan PPAT

3) adanya peraturan perundang-undangan lainnya yang mengatur tentang kewenangan PPAT.

${ }^{18}$ Ibid., hal. 57.

${ }^{19}$ Habib Adjie, Op. Cit., hal. 58. 


\section{Akibat Hukum Akta Pertanahan yang Dibuat oleh atau di Hadapan Notaris dan yang Dibuat oleh Pejabat Pembuat Akta Tanah}

Akibat hukum dari akta pertanahan yang dibuat oleh atau di hadapan Notaris jika ditinjau dari aspek hukum privat atau hukum perdata berdasarkan Pasal 1868 Kitab Undang-Undang Hukum Perdata yang menyebutkan:

Suatu akta autentik ialah suatu akta yang di dalamnya bentuk yang ditentukan oleh undang-undang. Dibuat oleh atau di hadapan pegawai-pegawai umum yang berkuasa untuk itu di tempat dimana akta itu dibuatnya, dan ketentuan akta yang dibuat oleh dan di hadapan notaris terdapat dalam Pasal 38 Undang-Undang Nomor 2 Tahun 2014 tentang Perubahan Atas undang-Undang nomor 30 tahun 2004 Tentang jabatan Notaris. ${ }^{20}$

Sehingga dapat dipahami bahwa akta pertanahan yang diamanatkan Pasal 15 ayat (2) huruf f Undang-Undang Nomor 2 Tahun 2014 Tentang Perubahan Atas Undang-Undang Nomor 30 tahun 2004 Tentang Jabatan Notaris, merupakan akta autentik yang memiliki kekuatan pembuktian sempurna (dapat memberikan kepastian hukum bagi para pihak) dengan catatan akta pertanahan tersebut memenuhi ketentuan Pasal 1320 KUH Perdata dan bukan merupakan akta yang menjadi kewenangan Pejabat Pembuat Akta Tanah (PPAT) sebagaimana dimaksud Pasal 2 Peraturan Pemerintah Nomor 37 Tahun 1998 Tentang Peraturan Jabatan Pejabat Pembuat Akta Tanah.

Sedangkan akta pertanahan yang dibuat oleh Pejabat Pembuat Akta Tanah (PPAT) berdasarkan kewenangannya yang menjadi amanat Pasal 2 Peraturan Pemerintah Nomor 37 Tahun 1998 Tentang Peraturan Jabatan Pejabat Pambuat Akta Tanah, setlah peneliti analisis dengan mengisterpretasikan secara sistematis dengan peraturan perundang-undangan yang berlaku di Indonesia. Jika dihubungkan dengan ketentuan Pasal 1868 Kitab Undang-Undang Hukum Perdata karena akta yang dibuat Pejabat Pembuat Akta Tanah (PPAT) di dalam bentuknya tidak ditentukan dengan Undang-Undang dan hanya ditentukan oleh Peraturan Pemerintah atau Peraturan Menteri sudah tentu dapat ditafsikan, akta yang dibuat oleh Pejabat Pembuat Akta Tanah (PPAT) bukan merupakan akta autentik dan memiliki kekuatan pembuktian

\footnotetext{
${ }^{20}$ Subekti dan Tjiptrosudibio, Kitab Undang-Undang Hukum Perdata “Burgelijk Wtboek”, PT. Prdanya Paramita, Jakarta, 2001, hal. 475.
} 
sebagai "surat dibawah tangan yang penilaiannya (jika bermasalah) diserahkan kepada hakim jika hal tersebut diperiksa atau menjadi objek gugatan pengadilan negeri."21

\section{Kesimpulan}

Berdasarkan temuan dan analisis, maka dapat disimpulkan, pertama, kewenangan Notaris bersumber dari atribusi yang melekat pada profesi Notaris sedangkan PPAT bersumber pada delegasi (pelimpahan wewenang) dari pejabat yang berwenang (BPN RI). Terhadap pengangkatan keduanya juga berbeda untuk Notaris dilakukan oleh Menteri Hukum dan Hak Asasi Manusia sedangkan PPAT dilakukan oleh Menteri Agraria/ Kepala Badan Pertanahan Republik Indonesia. Di antara keduanya juga tidak terdapat tumpang tindih kewenangan, dikarenakan terdapat perbedaan yang mendasar yang bersifat saling melengkapi.

Kedua, akta yang dibuat oleh atau di hadapan Notaris yang yang berkaitan dengan pertanahan yang diatur dalam Pasal 15 Ayat (2) huruf f Undang-Undang Nomor 2 Tahun 2014 Tentang Perubahan Atas Undang-Undang Nomor 30 Tahun 2004 Tentang Jabatan Notaris merupakan akta autentik dan memiliki kekuatan pembuktian sempurna karena telah memenuhi ketentuan akta autentik sebagaimana diatur dalam Pasal 1868 KUH Perdata sedangkan Akta Pejabat Pembuat Akta Tanah (PPAT) yang objeknya tanah yang diatur dalam Peraturan Pemerintah Nomor 37 Tahun 1998 Tentang Peraturan Jabatan Pejabat Pembuat Akta Tanah dikarenakan tidak memenuhi ketentuan akta autentik sebagaimana diatur dalam Pasal 1868 KUH Perdata sudah barang tentu bukan akta autentik dan hanya memiliki kekuatan pembuktian akta dibawah tangan.

\section{Daftar Pustaka}

Bahder Johan Nasution, Metode Penelitian Ilmu Hukum, Mandar Maju, Bandung, 2008.

Elita Rahmi, Hukum Pertanahan Dalam Sistem Hukum Indonesia, Unpad Press, Bandung, 2011.

Farida Patittingi, "Keberadaan Profesi Pejabat pembuat Akta Tanah (PPAT) di Tengah Kontroversi Payung Hukum”, http://ippatonline.com.

${ }^{21}$ Habib Adjie, Op. Cit., hal. 23. 
Habib Adjie, Merajut Pemikiran dalam Dunia Notaris dan PPAT, PT. Citra Aditya Bakti, Bandung, 2014.

Habib Adjie, Menjalin Pemikiran-Pendapat Tentang Kenotariatan (Kumpulan Tulisan), PT. Citra Aditya Bakti, Bandung, 2013.

Majalah Bulanan Notaris, PPAT, Pertanahan dan Hukum Renvoi, Nomor 9, 29 Februari 2014.

Subekti dan Tjiptrosudibio, Kitab Undang-Undang Hukum Perdata "Burgelijk Wtboek”, PT. Prdanya Paramita, Jakarta, 2001.

Sudikno Mertokusumo, Penemuan Hukum Sebuah Pengantar, Liberty, Yogyakarta, 2009. 